\title{
Global Distributive Justice and Education
}

\author{
Zdenko Kodelja \\ Educational Research Institute
}

\begin{abstract}
Global distributive justice is directly connected to the increased inequality in the world. This inequality, which includes the huge inequality of education opportunities, is usually understood as unjust. There are two main approaches to this problem: cosmopolitan and statist. Looking from the cosmopolitan point of view, this kind of injustice is related predominantly with the socio-economic relationships among the individuals on the planet. Just the opposite is the view of the so-called statists, who claim that a more just world is not a world of persons who are equal among themselves, but rather a world of nation states which are able to achieve a more just society within their borders and, consequently, a more just and egalitarian global society as well.
\end{abstract}

Keywords: global justice, distributive justice, education, political philosophy, cosmopolitanism

Global distributive justice has become one of the most prominent topics within contemporary political and moral philosophy. The main reason for this seems to be the need for the moral and political reflection of some negative consequences of the process of globalization and especially of the increased inequality in the world. This inequality—which refers to the growing gap between rich and poor, among individuals within a particular society and among nation states as well—is commonly understood as unjust. Despite this widely shared sense of injustice among philosophers, they do not agree on how we should treat this inequality. There are at least two approaches to this problem: cosmopolitan and statist. ${ }^{1}$ Looking from the cosmopolitan point of view, this kind of injustice is related predominantly with the socio-economic relationships among the individuals on the planet. The reason why cosmopolitans treat the discussed inequality from the individual's standpoint lies in the fact that they believe that individuals should be "the ultimate unit of moral concern and be entitled to equal consideration regardless of nationality and citizenship" (2004). ${ }^{2}$ Just the opposite is thought by the so-called statists. They claim that the fundamental moral units are institutions simply because "the principles of justice apply to institutions and not directly to individuals" (107). ${ }^{3}$ According to them, a more just world is not a world of persons who are equal among themselves, but rather a world of nation states which are able to achieve a more just society within their borders and consequently a more just and egalitarian global society as well. ${ }^{4}$ There is also an additional important distinction between these two approaches to global distributive justice. Cosmopolitans, in general, believe in the possibility of the theory of global distributive justice and in the full realisation of socio-economic human rights. In this sense, they can be understood as defenders of the idea of strong global justice. On the other hand, statists reject this idea because they are strongly persuaded that global distributive justice is neither theoretically defensible nor practically feasible. They accept only the validity of some socio-economic human rights and support humanitarian duties. According to Sebastiano Maffettone, both

Zdenko Kodelja, Ph.D., researcher and head of the Centre for Philosophy of Education at the Educational Research Institute, Slovenia; main research field: Political and Moral Philosophy, Justice, Research Ethics, Human Rights, Philosophy of Education. 
cosmopolitans and statists are mistaken. For, cosmopolitans tend to moralize international politics radically, considering political institutions simply as means to realize their preferred moral ideals; statists, on the contrary, tend to reduce, if not to eliminate, the space of morality in international politics. ${ }^{5}$

However, in spite of these controversies, it seems that both statists and cosmopolitans agree that human rights can "serve as a suitable starting point for working out a theory of global justice" (47). ${ }^{6}$

In fact, there are different theories of global justice which are based on human rights. In some of them, the right to education is recognized as one of the basic human rights, that is, as something that every human being is entitled to because (at least a minimum) education is a necessary condition for a life of dignity. ${ }^{7}$ This right entails-as well as all other human rights - the corresponding duty of governments to protect it and secure access to it. However, many poor countries have failed in their duty and consequently the right to education has been violated. According to John Rawls, rich countries have only a duty to help poor countries secure this right, that is, they have a duty of assistance, but not also a duty of justice whose aim is to regulate inequalities between countries. Although he rejects the idea of global distributive justice, some authors, such as Thomas Pogge and Charles Beitz, argue not only that duty of assistance is not enough, but that his two principles of justice (fair equality of opportunity and the difference principle), which are applied at the national level, should be applied globally as well. On the other hand, the connection between the universal duty of justice-which we have regardless of whether or not we are personally or collectively responsible for the violation of the right to basic education — can be considered, as Maffettone shows, as a first step toward one of the possible theories of global justice.

Moreover, David Miller and some other philosophers argue that the obligation to respect human rights worldwide is one of the conditions for global justice. A similar idea can also be found in the Preamble to the Universal Declaration of Human Rights, adopted by the United Nations General Assembly in 1948 in Paris, whose very first paragraph states, inter alia, that the recognition of human rights which are the same for all people is the foundation of justice in the world. ${ }^{8}$ It follows from this that justice in this world is greatly endangered if human rights are denied or violated as the foundation upon which global justice stands is thus being pushed from underneath it. This also applies to violations of the right to education, which is guaranteed to everyone in Article 26, whose first paragraph says: "Everyone has the right to education. Education shall be free, at least in the elementary and fundamental stages. Elementary education is compulsory. Technical and professional education shall be made generally available. Higher education shall be equally accessible to all on the basis of merit.” There is no doubt that this right, the exercise of which appears to be taken for granted in the developed world, is violated for many people and in many places. We can see this easily from information that a few years ago more than 121 million children were deprived of the most basic education, that at the same time $15 \%$ of girls did not attend primary school in as many as 70 countries, and that in sub-Saharan Africa alone more than 45 million children did not have an opportunity to acquire even elementary education. ${ }^{9}$ These and similar figures are indicative of two things. On the one hand, they bear witness to the injustice suffered by millions of children in different parts of the world; on the other hand, they highlight the huge differences in the global distribution of educational opportunities. Because educational opportunities are essential to ensuring equal opportunities and because without equality of opportunity there is no social justice, it is clear that great injustices are being done in the world in which we live. However, the injustices resulting from violations of the right to education as one of the fundamental human rights are far from being evenly distributed. They mainly take place in the most underdeveloped and extremely poor countries. Hence, nationality or membership of a 
particular nation is today a much stronger factor affecting the inequality of opportunity than are race, gender, or even talent and ability, as it is nationality that determines different educational opportunities and access to labour markets and to quite unequal systems of social rights. ${ }^{10}$ This, however, stands in stark contrast to the traditional concept of social justice, which requires that those who have the same abilities and equal will to learn must have not just equal opportunities for education but also for success in education, irrespective of their social status, race, nationality, religion, etc. But is it necessary and appropriate to expand this understanding of justice to the global level? There is no unique answer to this question. The main reason for this lies in the fact that there is no agreement regarding the answer to the question of whether global distributive justice should be understood as social justice in the sense that the principles of justice, accepted at the national level, should be extended to all mankind, or, just the opposite, if global justice should be understood as an inter-national justice, which requires the development of the principles that would enable fair interactions between nations or countries, which should be quite different from those principles that allow inter-individual equity within nations or nation states. ${ }^{11}$ Among the philosophers who are convinced that the principles of justice accepted at the national level should also be applied to the world as a whole are Beitz and Pogge. They both argue that such a principle is also Rawls's famous difference principle of justice, which requires social institutions to be arranged in such a way that social and economic inequalities "are to be to the greatest benefit of the least-advantaged members of society” (2001). ${ }^{12}$ However, some other political philosophers, for instance Thomas Nagel and, what is indicative, Rawls himself, unequivocally reject such interpretations. Moreover, they claim that global distributive justice is—in the world as it is now-impossible. In their opinion, it is impossible because there is no global justice without either a global people, or global democracy, or a global state, or a global basic structure. ${ }^{13}$ Some among these opponents of global distributive justice think that only humanitarian duties are needed on the global level. ${ }^{14}$ However, according to Maffettone, in the case of extreme inequality and poverty in the world, the moral obligations towards the poor of the globe do not "depend directly on the existence of a controversial global basic structure,” ${ }^{15}$ or, we can add, on a global people, global democracy, or a global state. He argues that there is a universal duty of justice, according to which "we have a duty to protect human dignity in all its forms, regardless of the presence of a real global basic structure” (119). ${ }^{16}$ This duty requires us to "help whoever is in extreme difficulty" regardless of whether or not "we are personally or collectively responsible for his or her hopeless situation" $(94 ; 117) .{ }^{17}$ Understood in such a way, a universal duty of justice — which is a form of positive duty to help—differs considerably from the negative duties not to harm the global poor, advocated by Pogge. ${ }^{18}$

A similar conclusion that we have such a universal duty of justice follows also from the famous argument given by Peter Singer in support of the thesis that the well-off people in rich countries have a moral duty to help poor people in poor countries. For, if we reconstruct his syllogism by replacing the first premise and, therefore, accept the following two premises, (1) suffering from the deprivation of basic education is something bad, and (2) if it is in our power to prevent something very bad from happening, without thereby sacrificing anything of comparable moral importance, we ought, morally, to do it, then the conclusion should be: people in rich countries have a moral obligation to help those in poor countries. Therefore, the answer to the question as to whether we ought to help to reduce the deprivation of basic education in poor countries is affirmative. But, how should we understand this: “ought to?” According to Singer, it should be understood as a duty. Therefore, we have a duty to help to reduce the deprivation of basic education in poor countries. This means that such help should not be considered as an act of charity or what "philosophers and theologians have called 
'supererogatory' - an act that it would be good to do, but not wrong not to do" (7). ${ }^{19}$ Charity is not an obligation. It is "something that we are free to do or to omit" (148). ${ }^{20}$ The claim that we have a duty to help others is therefore much more demanding than our moral obligations are usually understood. Usual interpretation of one's strict duty is: not to harm others. But helping others is morally optional. ${ }^{21}$

The question which arises here is: Who exactly has this duty? In Singer's analysis, a duty bearer is mostly an individual facing a moral choice. Just the opposite is thought by some other philosophers who argue that duty bearers are particular nation states. In their opinion, governments are those which have an obligation to ensure basic education to all people on the global level. As the right to education is one of the social rights, the government - to which the correspondent obligation belongs - must ensure conditions for its realization to the holder of the right. The aforementioned Universal Declaration of Human Rights and subsequent international conventions and covenants on human rights impose this obligation on States Parties. They have a legal obligation to ensure conditions for the exercise of these rights in their territory. The right to basic education is ensured by the majority of countries. As we have seen, however, some do not fulfill this duty. Some probably because they are so poor that they cannot do so, while others because they prefer to spend money on arming children with guns rather than with knowledge. The sad thing is that when it comes to violations of the right to education, the international community is, at the very least, helpless, if not even disinterested. The problem is that human rights, as Habermas emphasizes, have at the same time moral content and "the form of legal rights. Like moral norms, they refer to every” human being, "but as legal norms they protect individual persons only insofar as the latter belong to a particular legal community—normally the citizens of a nation state. Thus, a peculiar tension arises between the universal meaning of human rights and the local conditions of their realizations: They should have unlimited validity for all persons" (2001), ${ }^{22}$ but until now, this ideal has not yet been achieved. At the moment, it is still so that nobody can attain the "effective enjoyment of human rights immediately, as a world citizen,” because an "actually institutionalized cosmopolitan legal order" has not yet been established, although "Article 28 of the United Nations Universal Declaration of Human Rights refers to a global order 'in which the rights and freedoms set in this Declaration can be fully realized'” (118-9). ${ }^{23}$

Therefore, at the international or global level, there are no appropriate mechanisms in place to enable effective action in cases where countries do not fulfill their duties and thus violate this important human right. In such cases, according to Onora O’Neill, the role of the state should be assumed or at least supplemented by international institutions, transnational corporations, and nongovernmental organizations. ${ }^{24}$ The idea is interesting, but it raises some new questions. Nevertheless, it is a laudable attempt to find solutions to this pressing problem; as without its solution, without improving educational opportunities at the global level, there will be no greater global equity in education, which will harmfully impact global justice in general.

\section{Notes}

1. S. Maffettone, Un Mondo Migliore: Giustizia Globale tra Leviatano e Cosmopoli, Luiss University Press, Roma $2013,84$.

2. Cosmopolitans believe that individuals should be "the ultimate unit of moral concern and be entitled to equal consideration regardless of nationality and citizenship” (K-C. Tan, Justice without Borders: Cosmopolitanism, Nationalism and Patriotism, Cambridge University Press, Cambridge 2004, 1).

3. S. Maffettone, Un Mondo Migliore: Giustizia Globale tra Leviatano e Cosmopoli, 107.

4. Ibid., 85.

5. Ibid., 101-24. 
6. K-Ch. Tan, Justice without Borders, 47.

7. S. Maffettone, Un Mondo Migliore: Giustizia Globale tra Leviatano e Cosmopoli, Luiss University Press, Roma 2013, 116.

8. "Whereas recognition of the inherent dignity of all members of human society and of the equal and unalienable rights of the foundation of freedom, justice, and peace in the world...” (Universal Declaration of Human Rights, Introduction).

9. A. Spadano, Dai Diritti “Individuali” ai Doveri “Globali”, Catanzaro: Rubbettino, Editore, 2005, 110.

10. Ph. Van Parijs, “Qu'est-ce qu'une nation juste, un monde juste, une entreprise juste?” Lecture, l’Université catholique de Louvain, 13. 12. 2001.

11. T. Vandevelde, Ph. Van Parijs, Global Justice: Graduate Seminar in Ethics and Public Policy 2005-2006, Université catholique de Louvain, Louvain 2005-2006.

12. J. Rawls, Erin Kelly, Justice as Fairness: A Restatement, MASS: Harvard University Press, Cambridge 2001, 42-43.

13. Critical analysis of this dispute is in: Philippe Van Parijs, International Distributive Justice, in A Companion to Political Philosophy, eds. Robert E. Goodin, Philip Pettit, Thomas W. Pogge, Blackwell, Oxford 2007, 642-9.

14. Ibid., 641. They obviously agree with Rawls, who argues that the duty of assistance is sufficient for securing human rights and meeting basic needs in burdened societies. However, "if we accept that rich countries have only a duty of humanity to poorer countries, we are also accepting," says Kok-Chor Tan, "that the existing baseline resource and wealth distribution is a just one" (Tan, Justice without Borders, 66).

15. S. Maffettone, Un Mondo Migliore: Giustizia Globale tra Leviatano e Cosmopoli, 116.

16. Ibid. This universal duty and the correspondent basic socio-economic right to subsistence "rest on the characteristic of human vulnerability. They are imposed by the fact that our weakness as human beings requires a necessary support that cannot be deferred" (ibid., 119).

17. Ibid., 94; 117.

18. According to Pogge, the notion of "harming the poor" should be "understood as making them worse off than they should have been, i.e., how well off they would have been had the international economic order been just. To know what 'harming' is, one therefore needs to know what justice requires," and "not the other way round" (Van Parijs, International Distributive Justice, 649).

19. Ibid., 7. "Supererogation” is a term which means "paying out more than is due (super-erogare)," and it is used as a name "of actions that go "beyond the call of duty" (SEF).

20. O. O’Neill, “Rights, Obligations and World Hunger,” in: T. Pogge, K. Horton, Global Ethics, 148. Charity lies beyond one's duty. It is not required by justice: Giving what is owed to one as his right. For this reason, it is not the fulfillment of a duty for others' rights (SEF).

21. P. Singer, "Famine, Affluence, and Morality," 6-9.

22. J. Habermas, The Postnational Constellation, Polity Press, Cambridge 2001, 118.

23. Ibid., 118-9.

24. O. O’Neill, “Agents of Justice,” Metaphilosophy 2001/1-2, 180-95. 